\title{
Pest species of Macrolepidoptera in the Game Reserve of Velyka Dobron’ (Transcarpathia, Ukraine)
}

\author{
Szabolcs Szanyi ${ }^{1}$ - Antal Nagy ${ }^{2}$ - Attila Molnár ${ }^{3}$ - Miklós Tóth ${ }^{4}$ - Zoltán Varga ${ }^{1}$ \\ ${ }^{1}$ Department of Evolutionary Zoology, University of Debrecen, Hungary \\ ${ }^{2}$ Institute of Plant Protection, University of Debrecen, Hungary \\ ${ }^{3}$ Department of Biology and Chemistry, Ferenc Rákóczi II. Transcarpathian Hungarian Institute, Beregszász, Ukraine \\ ${ }^{4}$ Plant Protection Institute, CAR HAS, Budapest, Hungary \\ szanyiszabolcs@gmail.com
}

\begin{abstract}
SUMMARY
The Game Reserve of Nagydobrony extends on a marginal area of a former peatland and is covered with extended hardwood gallery forests and oak-hornbeam forests and is surrounded by a mosaic-like agricultural landscape. Due to its richness of nature-like and seminatural habitats it supports a diverse insect assemblage. By light and bait trapping 383 species of macro-moths were recorded from which larvae of 85 species are feeding either on forest trees and scrubs or on cultivated plants thus these can be considered as potential pest species. Thirteen species (mostly Geometridae and Erebidae: Lymantriinae) have a special significance for forestry due to defoliating activity in gradation periods. Considering the habitat connections, the composition of moth assemblage is dominated by generalist species with broad spectrum of ecological tolerance but the species connected with humid forested habitats are also richly represented. The bulk of species consists of widely distributed Euro-Siberian species, but also some Holo-Mediterranean species with more southern character and Mediterranean-Subtropical migrant species were registered. The bait trapping provided significant results on the phenology of the dominant species. The faunistically significant and/or protected species were observed in a low number of individuals only, thus the applied trapping methods did not damage the faunal composition.
\end{abstract}

Keywords: Macrolepidoptera, light trapping, bait traps, pest species, ecological spectrum, phenology

\section{INTRODUCTION}

The Bereg plain is located on the north-eastern edge of the Hungarian Great Plain. It is crossed by the Hungarian-Ukrainian border, and joining to the Transcarpathian lowland through the Chop-Munkachevo basin. Because of the traditional agriculture, a typical mosaic pattern of landscape structure was formed here. Some parts of the lowland are still rich in forests and wetlands (Simon, 1952). Owing to the position within the Carpathian basin, the region forms biogeography a transition between the Pannonicum and Carpathicum (Deli et al., 1997; Magura et al., 1997; Ködöböcz and Magura, 1999; Varga, 2003). Transcarpathia is one of the richest areas in Ukraine in terms of natural resources. Half of the vascular plants of Ukraine can be found there (Hrihora-Szolomaha, 2005). The entomofauna of the Hungarian part of the plain is relatively well studied, but most of the Ukrainian part was never surveyed by entomologists. Therefore our surveys are somewhat pioneering, even if these are aimed to well-known insect groups.

The area has the lowest temperature (the annual average: $8-9^{\circ} \mathrm{C}$ ), and highest amount of precipitation (609 $\mathrm{mm}$ in average) on the Great Plain, and simultaneously one of the most continental climate regions of the Carpathian basin (Simon, 1952). The relatively humid continental climate has allowed a nearly continuous afforestation of the Bereg lowland, dominated by pedunculate oak, hornbeam-oak and hardwood (oak-ash-elm) gallery forests. However, the percent of forest cover seriously declined to about $15 \%$ due to deforestation. These forests were mostly replaced by extended agricultural lands. The livelihood of majority of the human population is based on the agricultural production. The remaining forest areas were also increasingly used by logging and plantation of non indigenous trees, therefore most of these forest aren't in their natural state, but some of them is nearly natural. This mosaic landscape structure leads to very rich vegetation, which supports the high diversity of local insect fauna. The insect assemblages also include a lot of pest species too.

The Game Reserve of Nagydobrony (Velyka Dobron') belongs to the most valuable ones among the natural forests of Bereg plain, although its environmental condition should be regularly monitored with appropriate methods. The identification of forestry pest species is one of these primary tasks, including the surveillance of their population dynamics. Among the insect groups which can be collected by light, the nocturnal macro-moths are the richest in species, and also the most suitable herbivore group for the characterization of the condition of forest habitats (Kitching et al., 2000; Truxa, 2013). The long term data set (2009-2014) of light-trap surveys was used for this study, supplemented by bait trap results (in the summer of 2014), carried out in Game Reserve of Nagydobrony (Velyka Dobron'). All species were characterized by their zoogeographical character (faunal elements) and connection to habitat and food plant type (as faunal components). The observed species were also characterised according to their phenological character (voltinism, swarming period of moths). 


\section{MATERIALS AND METHODS}

\section{The description of the study area}

The Game Reserve of Nagydobrony (Velyka Dobron') is located on the marginal area of the former Szernyebog. Although the ancient vegetation and flora of the bog was very rich and valuable, the most important relict habitats and species became extinct. There are some fragments which still keep some species typical for marshyboggy habitats. The most extended habitat type of the reserve is the oak-ash-elm hardwood gallery forest (Fraxino-pannonicae-Ulmentum) with closed canopy layer. The canopy coverage is between $70-100 \%$. The dominant tree species of these habitats are: Quercus robur, Fraxinus angustifolia subsp. pannonica, Ulmus laevis, Populus canescens, etc. The lowland pedunculate oak-hornbeam forest (Circaeo-Carpinetum) is considered as the climax association of the region, which is zonal association in the higher regions. Other components of the nature-like and semi-natural vegetation are the more xerophilous silver lime - oak forests and forest fringes, the mesic and humid forest clearings and willow scrubs. The reserve is surrounded by extended agricultural areas and dissected by drainage channels of the former peatland.

\section{Methods}

The investigation of nocturnal macrolepidoptera species was started in 2009. The samplings were carried out by light-trapping, which is the most commonly used method for similar purposes. This method is based on the positive phototaxis of the target group. A mercury vapour lamp $(250 \mathrm{~W})$ combined with a large white sheet $(4 \times 3$ $\mathrm{m}$, in $1.5 \mathrm{~m}$ elevation) was used for collecting the moths.

Because the light trapping was highly affected by external environmental factors, bait traps were placed out, which contained different scent baits. These investigations were conducted in 2014. CSALOMON ${ }^{\circledR}$ VARL+ funnel traps (MTA ATK Plant Protection Institute, Budapest Hungary) were placed out baited with synthetic compounds previously isolated and identified from fermenting bait liquids (= FERM) (Landolt, 2000) or with synthetic floral compounds (= FLORAL), which was previously isolated and identified from the flower scent of several plants (for a review refer to Knudsen et al, 1993). Traps without baits were also set out for control.

Polypropylene tubes with $4 \mathrm{ml}$ capacity were used as dispensers for the FERM bait (Tóth et al., 2015). The synthetic compounds were administered on the dental rolls inside the tubes. The upper, larger opening of the tube was closed. The bait mixture could evaporate across the smaller opening with $4 \mathrm{~mm}$ diameter, which was opened when setting out in the field. The attractant contained iso-amyl alcohol, acetic acid and red wine (1: 1: 1; $3 \mathrm{ml}$ ). The wine was prepared (cellary of Dr. G. Vörös) by processing of different grape sorts: Bluefrankish (70\%), Merlot (15\%), Kadarka (7,5\%) and Blauburger (7,5\%). Its alcohol content was 13.6-13.8 \%, the volatile acid (acetic acid) content was 0.4-0.6 g/l. Traps with the FLORAL lure were baited with two separate polyethylene bag dispensers (Tóth et al., 2002). One of the dispensers contained the mixture (1:1:1, $0.6 \mathrm{ml})$ of phenylacetaldehyde, eugenol and benzyl acetate, while the second dispenser contained a mixture $(1: 1,0,4 \mathrm{ml})$ of phenylacetaldehyde and trans-anethol.

All bait trap types were exposed in four repetitions, i.e. $4 * 3$ traps were placed in the survey area on trees, in $20 \mathrm{~m}$ distance from each other, at 1.8-2 m elevations. The traps were placed to trees which were situated in the edge of a sampling site. To avoid positional effects of different trap positions, the traps were rotated between locations at each inspection. The traps were operated between 20th July and 19th October. The trapped moths were killed by an insecticide strip. They were emptied once in a week. The collected material was stored deepfrozen until identification.

The Noctuoidea taxa were identified according to the works of Kádár et al. (2010), Mészáros and Szabóky (2012), but mostly Varga et al. (2011). For the nomenclature and characterization of species the book „Magyarország Nagylepkéi” (Varga /ed./ 2011) was used. For the selection of pest species the publications of Szabóky and Leskó (1999) and Both et al. (2012) were used. For the fauna element and component information the 3rd volume of „A Magyar Állatvilág Fajjegyzéke” (Varga et al. 2004, Macrolepidoptera) was used.

\section{RESULTS AND DISCUSSION}

During the investigation 383 nocturnal macrolepidoptera species were identified. Within that there were 85 potential forestry and agricultural pest species (65 were collected by light trapping only, 18 with both methods, and 2 just with bait trapping) (Table 1). Among them there were 13 species (bold) which already caused serious damages in some forests of the Bereg lowland.

The quantitative information coming from bait trapping is very preliminary only, thus it may not represent fully the ratio of potential pest species. 
The list of pest species (A - light trap; B - bait trap with semisynthetic and synthetic attractants)

\begin{tabular}{|c|c|c|c|c|c|}
\hline SPECIES & A & B & SPECIES & A & B \\
\hline LASIOCAMPIDAE & & & NOTODONTINAE & & \\
\hline Malacosoma neustrium (Linnaeus, 1758) & + & & Furcula bifida (Brahm, 1787) & + & \\
\hline Poecilocampa populi (Linnaeus, 1758) & + & & Stauropus fagi (Linnaeus, 1758) & + & \\
\hline Trichiura crataegi (Linnaeus, 1758) & + & & Drymonia ruficornis (Hufnagel, 1767) & + & \\
\hline Lasiocampa quercus (Linnaeus, 1758) & + & & Pheosia tremula (Clerck, 1759) & + & \\
\hline Gastropacha quercifolia (Linnaeus, 1758) & + & & Spatalia argentina ([Den. et Schiff.], 1775) & + & \\
\hline SPHINGIDAE & & & Ptilodon capucina (Linnaeus, 1758) & + & \\
\hline Laothoe populi (Linnaeus, 1758) & + & & Ptilophora plumigera ([Den. et Schiff.], 1775) & + & \\
\hline Mimas tiliae (Linnaeus, 1758). & + & & Phalera bucephala (Linnaeus, 1758) & + & \\
\hline SATURNIIDAE & & & Clostera anastomosis (Linnaeus, 1758) & + & \\
\hline Saturnia pyri ([Den. et Schiff.], 1775)* & + & & EREBIDAE & & \\
\hline DREPANIDAE & & & Scoliopteryx libatrix (Linnaeus, 1758) & + & + \\
\hline Drepana falcataria (Linnaeus, 1758) & + & & Lymantria dispar (Linnaeus, 1758) & + & \\
\hline Watsonalla binaria (Hufnagel, 1767) & + & & Lymantria monacha(Linnaeus, 1758) & + & \\
\hline THYATIRIDAE & & & Euproctis chrysorrhoea (Linnaeus, 1758) & + & \\
\hline Thyatira batis (Linnaeus, 1758) & + & + & Sphrageidus similis (Fuessly, 1775) & + & \\
\hline Tethea or ([Den. et Schiff.], 1775) & + & + & Orgyia antiqua (Linnaeus, 1758) & + & \\
\hline Habrosyne pyrithoides (Hufnagel, 1766) & + & + & Arctornis l-nigrum (Müller, 1764) & + & \\
\hline GEOMETRIDAE & & & Leucoma salicis (Linnaeus, 1758) & + & \\
\hline Cyclophora linearia (Hübner, 1799) & + & & Spilarctia lutea (Hufnagel, 1766) & + & \\
\hline Chlorochlysta siterata (Hufnagel, 1767) & + & & Spilosoma lubricipedum (Linnaeus, 1758) & + & \\
\hline Dysstroma truncata (Hufnagel, 1767) & + & & Hyphantria cunea (Drury, 1773) & + & \\
\hline Epirrita dilutata ([Den. et Schiff.], 1775) & + & & Arctia caja (Linnaeus, 1758) & + & \\
\hline Operophtera brumata (Linnaeus, 1758) & + & & Lithosia quadra (Linnaeus, 1758 & + & + \\
\hline Chloroclystis v-ata (Haworth, 1809) & + & & Catocala fraxini (Linnaeus, 1758) & & + \\
\hline \multirow[t]{2}{*}{ Abraxas grossulariata (Linnaeus, 1758) } & + & & Nycteola asiatica (Krulikovsky, 1904) & + & \\
\hline & & & NOCTUIDAE & & \\
\hline Lomaspilis marginata (Linnaeus, 1758) & + & & Autographa gamma (Linnaeus, 1758) & + & + \\
\hline Macaria liturata (Clerck, 1759) & + & & Colocasia coryli (Linnaeus, 1758) & + & \\
\hline Chiasmia chlathrata (Linnaeus, 1758) & + & & Acronicta megacephala ([Den. et Schiff.], 1775) & & + \\
\hline Plagodis dolabraria (Linnaeus, 1767) & + & & Acronycta rumicis (Linnaeus, 1758) & + & + \\
\hline Epione repandaria (Hufnagel, 1767) & + & & Heliothis peltigera ([Den. et Schiff.], 1775) & + & \\
\hline Ennomos quercinaria (Hufnagel, 1767) & + & & Helicoverpa armigera (Hübner, 1808) & + & + \\
\hline Selenia dentaria (Fabricius, 1775) & + & & Phlogophora meticulosa (Linnaeus, 1758) & + & + \\
\hline Colotois pennaria (Linnaeus, 1761) & + & & Cosmia trapezina (Linnaeus, 1758) & + & + \\
\hline Apocheima hispidaria ([Den. et Schiff.], 1775) & + & & Conistra vaccinii (Linnaeus, 1761) & + & + \\
\hline Lycia hirtaria (Clerck, 1759) & + & & Agrochola circellaris (Hufnagel, 1766) & + & + \\
\hline Biston betularius (Linnaeus, 1758) & + & & Mamestra brassicae (Linnaeus, 1758) & + & \\
\hline Biston strataria (Hufnagel, 1767) & + & & Lacanobia suasa ([Den. et Schiff.], 1775) & + & + \\
\hline Agriopis marginaria (Borkhausen, 1777) & + & & Lacanobia oleracea (Linnaeus, 1758) & + & + \\
\hline Agriopis aurantiaria (Hübner, 1799) & + & & Orthosia cruda ([Den. et Schiff.], 1775) & + & \\
\hline Erannis defoliaria (Clerck, 1759) & + & & Orthosia gothica (Linnaeus, 1758) & + & \\
\hline Peribatodes rhomboidaria ([Den. et Schiff.], 1775) & + & & Agrotis exclamationis (Linnaeus, 1758) & + & + \\
\hline Hypomecis roboraria ([Den. et Schiff.], 1775) & + & & Agrotis segetum ([Den. et Schiff.], 1775) & + & + \\
\hline Hypomecis punctinalis (Scopoli, 1763) & + & & Agrotis ipsilon (Hufnagel, 1766) & + & \\
\hline Ectropis crepuscularia ([Den. et Schiff.], 1775) & + & & Noctua pronuba (Linnaeus, 1758) & + & + \\
\hline Cabera pusaria (Linnaeus, 1758) & + & & Xestia c-nigrum (Linnaeus, 1758) & + & + \\
\hline Campaea margaritata (Linnaeus, 1767) & + & & & & \\
\hline
\end{tabular}

[*Den. et Schiff. $=$ Denis and Schiffermüller $]$ 
Figure 1: The composition (\%) of potential pest species in the surveyed material by families

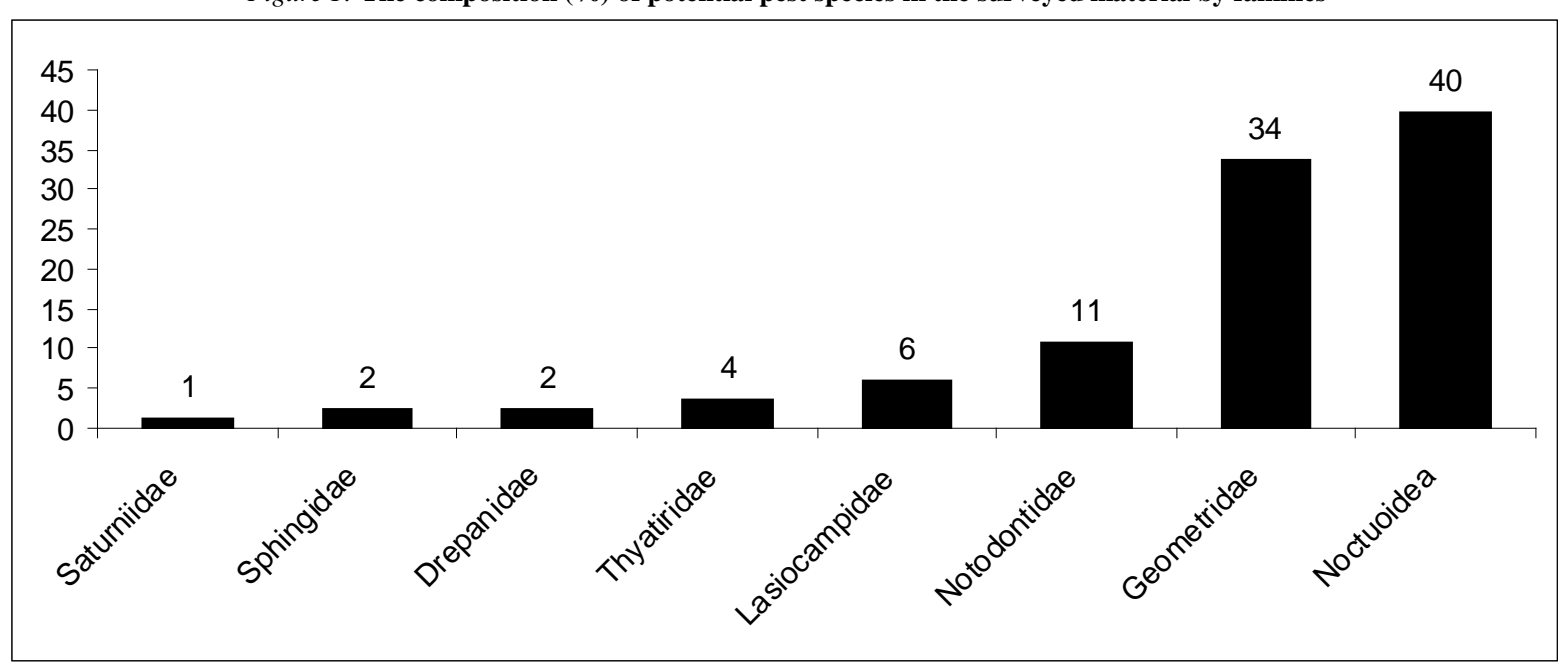

The greatest threat was caused until yet by the gypsy moths (Erebidae: Lymantriinae), which belongs to the Noctuoidea superfamily, and also from the early spring or late autumn Geometridae (Figure 1), of which caterpillars are hatching before leafing out. It has to be mentioned, that all of the important Hungarian forestry pest gypsy moth species were recorded: Lymantria dispar (Linnaeus, 1758), L. monacha (Linnaeus, 1758), Euproctis chrysorrhoea (Linnaeus, 1758), Sphrageidus similis (Fuessly, 1775) and Leucoma salicis (Linnaeus, 1758). 2).

The distribution of different faunal components reflect to the linkage of species to the habitat types (Figure

Figure 2: Proportion of the ecological groups (faunal components) (\%)

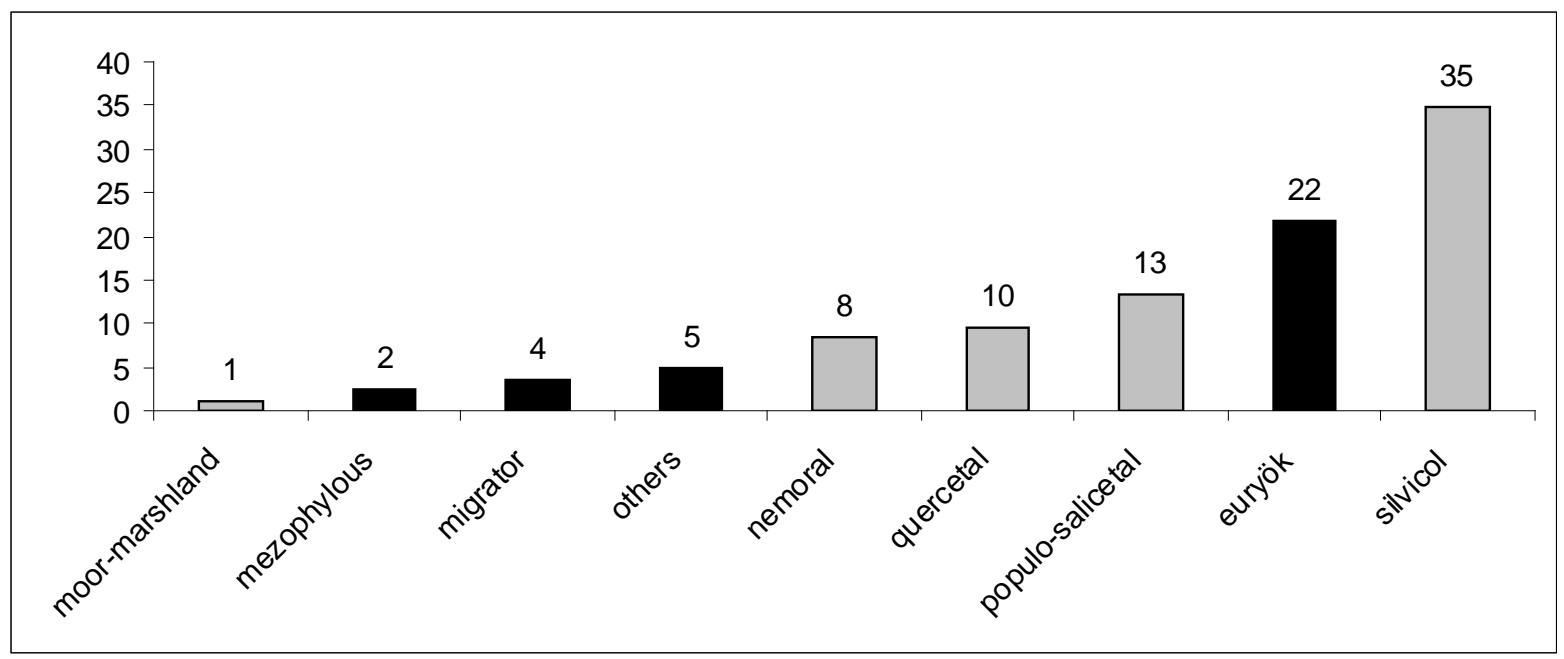

Considering the composition of the vegetation of the area, it was expectable that the euryoecious species are dominating. The bulk of species linked to forest habitats belong to the generalist forest species (silvicolous), but also the softwood (populo-salicetal), and oak-wood (quercetal) etc. species (grey columns) are abundantly represented. Between these species, which are linked to the forest habitats, there were several which can cause the mass defoliattion of pedunculate oak forests, e.g. Operophtera brumata (Linnaeus, 1758), Agriopis aurantiaria (Hübner, 1799), Colotois pennaria (Linnaeus, 1761) and Erannis defoliaria (Clerck, 1759) from the Geometridae family. All of these species are prone to gradation, which repeat periodically in every 9-12 years (Szontagh, 1985).

The collected species can also be characterized zoogeographically as faunal elements. It is clear that most of the species belong to Euro-Siberian faunal elements (Figure 3). 
Figure 3: Zoogeographic divergence of species (\%)

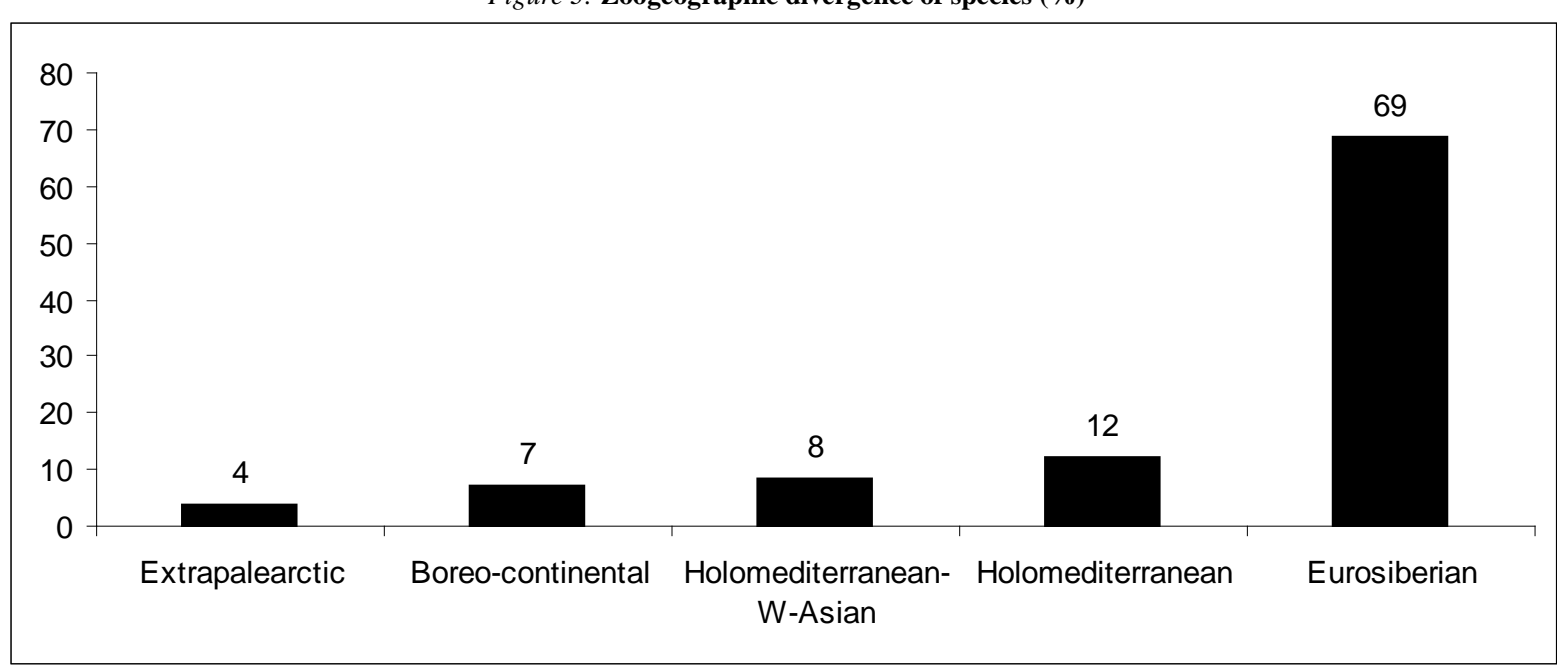

Most of these show a wide spectrum of tolerance and thus they are widespread and frequent species in the Carpathian basin. Most of these can live in disturbed, secondary habitats, too. They can find favorable conditions since the sampling sites are surrounded by fields used for agriculture, or they are partially abandoned areas. There are also some species, which have southern connections e.g. the Holo-Mediterranean Drymonia ruficornis (Hufnagel, 1767), Biston strataria (Hufnagel, 1767), Heliothis peltigera ([Denis et Schiffermüller], 1775), etc. The northern component is composed by some few boreo-continental species, as Catocala fraxini (Linnaeus, 1758), Lymantria monacha (Linnaeus, 1758), Dysstroma truncata (Hufnagel, 1767), etc.

The bait traps have shown that the first peak of the collected species appears in mid-summer. It is gradually decreasing to the direction of autumn. However it is followed by a smooth increase (Figure 4).

Figure 4: The number of species collected by the bait traps in weekly subdivision

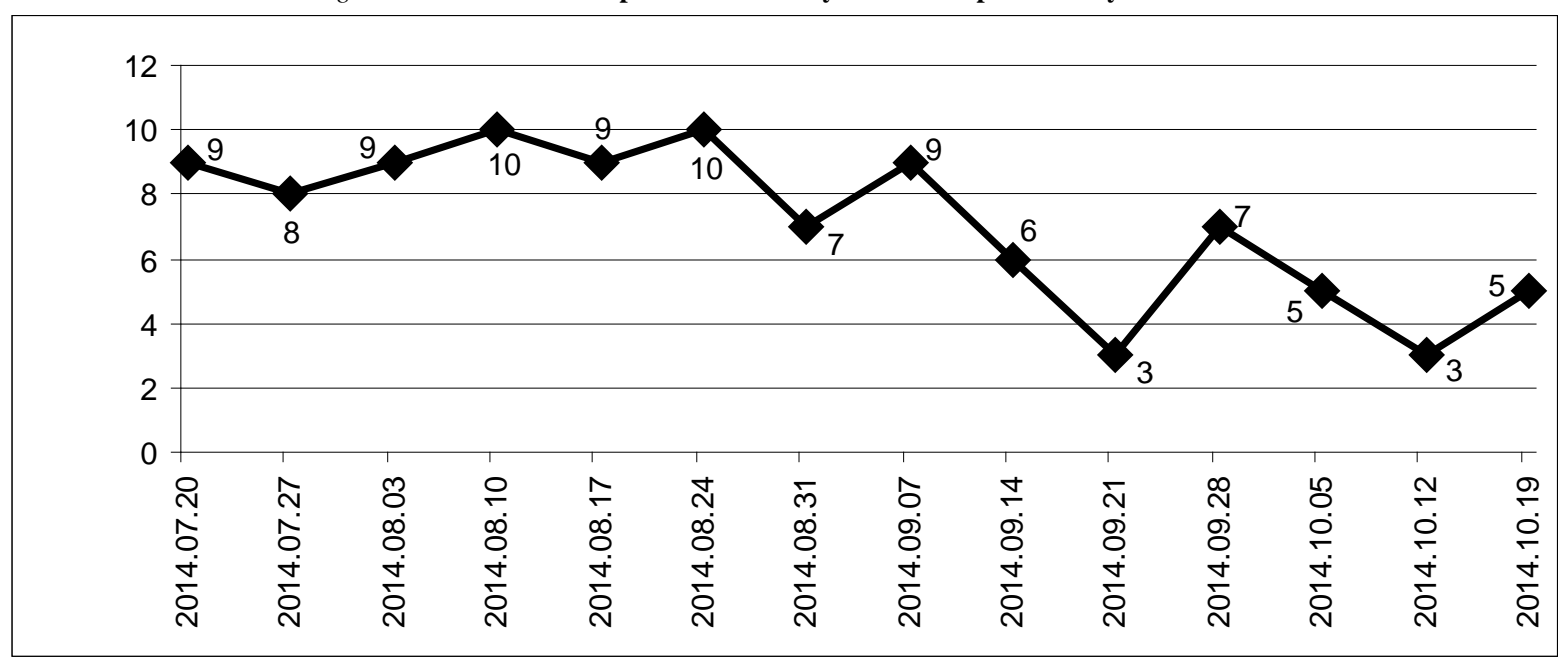

This first peak is connected with appearance of polyphagous species feeding on herbaceous plant species. Their summer (second!) generation flies in mid-late summer period until the early autumn. This period is followed by a faunal change, when the species connected to herbaceous plants are replaced by univoltine species feeding on forest trees or scrubs. It has to be mentioned, that the bait traps did not collect those pest species from which the imagoes do not feed (e.g. autumnal Geometridae).

The number of individuals shows a similar general picture as number of species (Figure 5) although in contrast with the species number, the number of individuals displays a stronger increase in the autumn period. 
Figure 5: The number of individuals collected by the bait traps in weekly subdivision

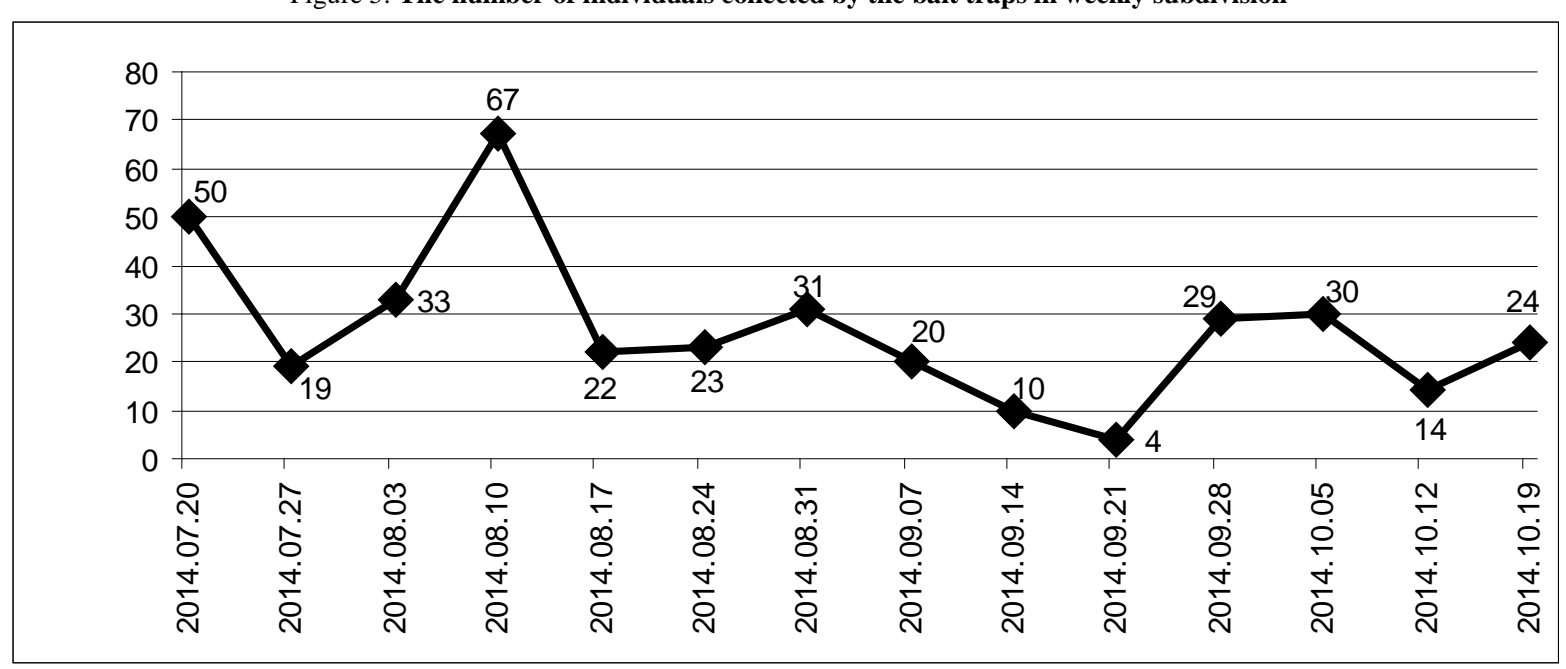

Here is the place to note that despite the large number of species and individuals, the faunistically significant and/or protected species were observed in rather low number of individuals only. Therefore the applied sampling methods did not damage the faunal composition but signalised the potential threats for the forestry in this biogeographically significant transitional region.

\section{ACKNOWLEDGEMENTS}

We are grateful to Krisztián Katona for his collaboration in the field work. Szabolcs Szanyi was supported by the Collegium Talentum grant of the Edutus High School.

\section{REFERENCES}

Deli, T. - Sümegi, P. - Kiss, J. (1997): Biogeographical characterisation of the Mollusc fauna on Szatmár-Bereg Plain. - In: Tóth, E. Horváth, R. (eds): Proceedings of the „Research Conservation, Management” Conference (Aggtelek) 1-5 May 1966. - ANP Füzetek Aggtelek Vol I. pp. 123-129.

Hrihora, I. M. - Szolomaha, V. А. (Григора, I. М. - Соломаха В. А.) (2005): Рослинність України. Киев, Український фітосоціологічний центр.

Kádár M. - Petrányi G. - Ronkay G. - Ronkay, L. (2010): A magyarországi bagolylepkék (Lepidoptera, Noctuidae) fényképes határozója. (Photographic identification guide to the noctuids (Lepidoptera, Noctuidae) of Hungary). Szalkay József Magyar Lepkészeti Egyesület. Budapest.

Kitching, R. L. - Orr, A. G. - Thalib, L. - Mitchell, H. - Hopkins, M. S. - Graham, A. W. (2000): Moth assemblages as indicators of environmental quality in remnants of upland Australian rain forest. Journal of Applied Ecology 37: $284-297$.

Knudsen J.T. - Tollsten L. - Bergström L.G.(1993): Floral scents - a checklist of volatile compounds isolated by head-space techniques. Phytochemistry, 33:253-280.

Ködöböcz, V. - Magura, T. (1999): Biogeographical connections of the carabid fauna (Coleoptera) of the Beregi-síkság to the Carpathians. Folia entomologica hungarica 60: 195-203.

Landolt, P. J.(2000): New chemical attractants for trapping Lacanobia subjuncta, Mamestra configurata, and Xestia c-nigrum (Lepidoptera: Noctuidae). Journal of Economical Entomology 93: 101-106.

Magura, T. - Ködöböcz, V. - Tóthmérész, B. - Molnár, T. - Elek, Z. - Szilágyi, G. - Hegyessy, G. (1997): Carabid fauna of the Beregi-síkság and its biogeographical relations (Coleoptera Carabidae). Folia Entomologica Hungarica 58: 73-82.

Mészáros Z. - Szabóky, Cs. (2012): A magyarországi nagylepkék gyakorlati albuma. Szalkay József Magyar Lepkészeti Egyesület. Budapest, 185 pp.

Simon, T. (1952): Mountain elements in the flora and vegetation of the Northern Lowland [Montán elemek az Észak-Alfóld fiórájában és növénytakarójában. In Hung.] Annales Biologicae Universitatis Debreceniensis 1:146-174.

Szabóky, Cs. - Leskó, K. (1999): Lepidoptera - lepkék. 354 - 409. In: Tóth, J. (Szerk.): Erdészeti rovartan. Agroinform kiadó. Budapest.

Szontagh P. (1985) Tölgy nagylepke károsítóinak populációdinamikája és a másodlagos károsító rovarok okozta kárláncolat. Erdészeti Kutatások 1985. 76-77: 305-314

Tóth, M. - Répási, V. - Szőcs, G. (2002) Chemical attractants for females of pest pyralids and phycitids (Lepidoptera: Pyralidae, Phycitidae) Acta Phytopath. Entomol. Hung. 37:375-384.

Tóth, M. - Szarukán, I. - Nagy, A. - Gém, F. - Nyitrai, R. - Kecskés, Zs. - Krakkó, L. - Jósvai, J. - Bélai, I (2015): Félszintetikus "biszex" csalétkek kártevő rovarok nőstényeinek és hímjeinek fogására. Növényvédelem 51:197-205.

Truxa, Ch. (2013): Community ecology of moths in floodplain forests of Eastern Austria. Ph.D. Dissertation, Universität Wien, pp. 112.

Varga, Z. (2003): Zoogeography of the Carpathian Basin. [A Kárpát-medence állatföldrajza in Hung.]. In: Láng, I., Bedő, Z., Csete, L. (eds.): Növény, állat, élőhely. Magyar Tudománytár III pp. 89-119. 
Varga, Z. - Ronkay, L. - Bálint, Zs. - Gyula, L. M. - Peregovits, L. (2004): Checklist of the fauna of Hungary. Volume 3. Macrolepidoptera. - Hungarian Natural History Museum, Budapest, 106 pp.

Varga, Z. (Ed.) (2011): Magyarország nagylepkéi - Macrolepidoptera of Hungary. Heterocera Press, Budapest, pp. 354. 